\title{
Persistently Circulating C3 Nephritic Factor (C3 NeF)-Stabilized Alternative Pathway C3 Convertase (C3 CoF) in Serum of an 11-Year-Old Girl with Meningococcal Septicemia-Simultaneous Occurrence with Free C3 NeF
}

\author{
V. WAHN, W. MÜLLER, C. RIEGER, AND U. ROTHER \\ Universitäts-Kinderklinik, Düsseldorf [V.W.]; Kinderklinik der MHH, Hanover [W.M.]; \\ Universitäts-Kinderklinik, Marburg [C.R.]; and Institut für Immunologie und Serologie, Heidelberg [U.R.], FRG
}

\begin{abstract}
Hemolytic complement was found to be absent in the serum of an 11-yr-old girl (R.N.) with meningococcal septicemia. $\mathrm{C1}, \mathrm{C} 4$, an $\mathrm{C} 2$ were slightly decreased, C3 was absent, C5-C9 within the normal range. B levels immunochemically and electrophoretic mobility of $B$ were normal. C3d was $>1000 \%$ of a pooled EDTA-plasma standard indicating hypercatabolism of C3. On incubation of the patient's serum with normal human serum activation of $\mathrm{C} 3$ occurred even in the presence of $0.04 \mathrm{M}$ EDTA. The amount of C3b generated was, however, greater without any chelating agent or in Mg-EGTA. On gel filtration of the serum two protein containing peaks were found to be responsible for activation of $\mathrm{C} 3$ : the IgG containing peak was able to activate $\mathrm{C3}$ in normal human serum without chelating agents and in Mg-EGTA but not in the presence of EDTA. The IgM-containing peak activated the third component of complement even in the presence of EDTA. The factor responsible for this phenomenon was termed $\mathrm{C} 3$ converting factor $(\mathrm{C} 3 \mathrm{CoF})$. The IgG fraction of the patients serum caused activation of $\mathrm{C} 3$ in Mg-EGTA. However, in the presence of EDTA no activation of $\mathrm{C} 3$ could be induced even if physiological concentrations of the patients IgG were added to normal human EDTAplasma. Thus the activity of the patient's IgG did not differ from typical $\mathrm{C} 3$ nephritic factor. The decay of $\mathrm{C} 2$ in EAC42 intermediates in the presence of the patient's IgG was uninfluenced indicating that it did not carry autoantibody activity against the classical pathway convertase $C 4 b, 2 a$, an activity recently termed NFc. As the ability of the patient's serum to activate $\mathrm{C} 3$ in the presence of excess EDTA was still unexplained further analyses were performed. $\mathrm{C} 3 \mathrm{CoF}$ was found to be a $\beta$ 2-euglobulin and could be separated from IgG by anion exchange chromatography following euglobulin precipitation. C3 conversion with this material was independent from $\mathrm{Ca}^{2+}$ and $\mathrm{Mg}^{2+}$. It was partly heat resistant at $56^{\circ} \mathrm{C}$ and could not be inhibited by soy bean trypsin inhibitor at $5 \mathrm{mg} / \mathrm{ml}$. In contrast, DFP at $5 \mathrm{mM}$ concentration lead to approximately $50 \%$ inhibition indicating that $\mathrm{C3} \mathrm{CoF}$ might be a serine protease. Treatment of patient's EDTA plasma with anti-C3 or anti-B totally eliminated $\mathrm{C} 3 \mathrm{CoF}$ activity while antialbumin, anti-
\end{abstract}

Received October 17, 1986; accepted February 19, 1987

Reprint requests Prof. Dr. V. Wahn, Universitäts-Kinderklinik, Moorenstr. 5, D 4000 Düsseldorf, FRG.
C2, anti-C4, or nonimmune rabbit-IgG did not. Precipitation with anti-IgG partly eliminated $\mathrm{C} 3 \mathrm{CoF}$ but absorption of serum with an anti-IgG affinity column totally eliminated $\mathrm{C} 3 \mathrm{CoF}$; these observations suggest that $\mathrm{C} 3 \mathrm{CoF}$ may be a $\mathrm{C} 3 \mathrm{NeF}$-stabilized alternative pathway $\mathrm{C} 3$ convertase. (Pediatr Res 22: 123-129, 1987)

\section{Abbreviations}

C3 NeF, C3 nephritic factor $\mathrm{C} 3 \mathrm{CoF}, \mathrm{C} 3$ converting factor NHS, normal human serum RNS, serum of patient RN NHPI, normal human EDTA-plasma IEP, immunoelectrophoresis MPGN, membranoproliferative glomerulonephritis

C3 AF, C3 activating factor

ESR, erythrocyte sedimentation rate WBC, white blood cells

AHG, aggregated human $\gamma$-globulin

PBS, phosphate-buffered saline

SBTI, soy bean trypsin inhibitor

DFP, diisopropylfluorophosphate

DIC, disseminated intravascular coagulation

PMNL, polymorphonuclear leucocytes

C-EDTA, complement EDTA

Various states of hypercatabolism of the third component of the complement system, C3, have been described (1). Two of them, the deficiencies of factors $I$ and $H$, were identified as genetic defects $(2,3) . \mathrm{H}$ and I function as regulatory proteins of the alternative pathway by degrading $\mathrm{C} 3 \mathrm{~b}$ to $\mathrm{iC} 3 \mathrm{~b}$ which in turn can be cleaved to $C 3 \mathrm{c}$ and $\mathrm{C} 3 \mathrm{~d}$ by a trypsin-like enzyme $(4,5)$. The absence of $\mathrm{H}$ or I leads to the persistence of $\mathrm{C} 3 \mathrm{~b}$ which combines with factor B and, in the presence of factor D, forms the alternative pathway convertase $\mathrm{C} 3 \mathrm{~b}, \mathrm{Bb}(6)$. Persistence of this enzyme is associated with continuous activation and consumption of $\mathrm{C} 3 . \mathrm{Mg}^{2+}$ is essential for its action.

Besides these two genetic deficiences various states of hypercatabolism of $\mathrm{C} 3$ have been identified without evidence of familality. The most common cause is activation of complement by circulating immune complexes (CIC, 7) which depends on 
the presence of both $\mathrm{Ca}^{2+}$ and $\mathrm{Mg}^{2+}$. C3 Nef has been found in sera of patients with MPGN, partial lipodystrophy, and meningococcal meningitis (8-10). It is an IgG-autoantibody directed against $\mathrm{C} 3 \mathrm{~b}, \mathrm{Bb}(11,12)$ which stabilizes the enzyme and prevents its intrinsic decay (13). C3 Nef requires $\mathrm{Mg}^{2+}$ for its action.

An analogue directed against the classical pathway convertase $\mathrm{C} 4 \mathrm{~b}, 2 \mathrm{a}$ has been detected in serum of a patient with acute glomerulonephritis (NFc, 1). It is probably identical with the F-42 autoantibody found in some SLE-sera $(14,15)$. It seems to prevent the intrinsic decay of $\mathrm{C} 4 \mathrm{~b}, 2 \mathrm{a}$ as well as the extrinsic decay mediated by $\mathrm{C} 4$ binding protein (16). In addition, $\mathrm{C} 4 \mathrm{~b}$ in the stable convertase $\mathrm{C} 4 \mathrm{~b}, 2 \mathrm{a}$ is protected from the proteolytic action of factor I (16). C4b,2a, thus stabilized, may activate $\mathrm{C} 3$ even in EDTA (17). For the formation of $\mathrm{C} 4 \mathrm{~b}, 2 \mathrm{a}$, however, $\mathrm{Mg}^{2+}$ is essential.

Two more activators of $\mathrm{C} 3$ have been reported. Hypercatabolism type II (18) identified in a patient with recurrent infections was due to a $6 \mathrm{~s}$ heat-labile pseudoglobulin enzyme which also depended on the presence of $\mathrm{Mg}^{2+}$. $\mathrm{C} 3 \mathrm{AF}$, a $\gamma$-migrating nonIgG activator of $\mathrm{C} 3$ found in the cryoprecipitate of a patient with MPGN (19), also required $\mathrm{Mg}^{2+}$.

Thus, except for the nephritic factor of the classical pathway $\mathrm{NFc}$ which is an IgG, all the known C3 converting activities depend on $\mathrm{Mg}^{2+}$. Herein we describe a factor $(\mathrm{C} 3 \mathrm{CoF})$ which does not require divalent cations and is composed of $\mathrm{C} 3, \mathrm{~B}$, and IgG.

\section{CASE REPORT}

The family history of patient R.N. was unremarkable as was her own history until the age of $11 \mathrm{yr}$. Ten days prior to admission to the hospital she had an episode of otitis media which was treated with amoxycillin for 3 days. One week later she became febrile again and began to vomit. In addition pain and tenderness of the left knee and some finger joints occurred.

On physical examination after admission she had a temperature of $40.4^{\circ} \mathrm{C}$ and a generalized maculopapulour, partially petechial rash. We noticed marked lymphadenopathy and slight hepatosplenomegaly. Meningeal signs were absent.

Laboratory findings. ESR 42/72, red cell count normal, WBC $26900 / \mathrm{mm}^{3}$ with 2 bands, 84 polymorphs, 1 eosinophil, 7 lymphocytes, and 6 monocytes. Platelets $163000 / \mathrm{mm}^{3}$. Coagulation tests revealed no evidence of DIC. Rheumatoid factor and antinuclear antibodies were negative, circulating immune complexes (in the first serum) by Clq binding assay were slightly increased. Total hemolytic complement was hardly detectable, C4 immunochemically was normal, C3 undetectable. Blood cultures revealed Neisseria meningitidis. CSF: 30 leucocytes/ $\mathrm{mm}^{3}$ (24 PMNL, 6 mononuclear cells), cultures sterile. Evidence of renal disease was found neither at the time of admission nor during the 3 yr observation period following recovery.

Treatment was initiated with ampicillin $(300 \mathrm{mg} / \mathrm{kg}$ body weight/day) and tobramycin (5 mg/ $\mathrm{kg}$ body weight/day) and continued with penicillin $\mathrm{G}$ after identification of meningococci. Clinical improvement and normal temperature was achieved within $24 \mathrm{~h}$. After 10 days of treatment antibiotic therapy was discontinued.

After complete recovery from her illness (for now approximately $3 \mathrm{yr}$ ) $\mathrm{CH} 50$ - and C3-levels remained undetectable and therefore further analyses of the complement system were performed (see "Results"). Analyses of the parent's sera revealed normal total hemolytic complement activity and normal levels for C3.

\section{MATERIALS AND METHODS}

Sera. Venous blood was obtained and allowed to clot for 30 $60 \mathrm{~min}$ at room temperature. After centrifugation serum was kept in aliquots at $-70^{\circ} \mathrm{C}$ until use. EDTA-plasma was prepared similarly using EDTA-coated tubes. (NHS and NHP1) was ob- tained from 30 healthy volunteers from the clinic staff and pooled. These pools served as reference standards for all complement determinations.

Titrations of total hemolytic complement and individual components were performed according to Mayer (20). Cellular intermediates EA, EAC4, EAC1, and EAC1,4 were prepared in our laboratory as described (21). EAC1-7 and functionally purified $\mathrm{C}$ components were purchased from Cordis (Miami, FL) or prepared according to Rapp and Borsos (22). Alternative pathway lysis was measured using rabbit erythrocytes in Mg-EGTA buffer according to Platts-Mills and Ishizaka (23).

Immunochemical determinations of $\mathrm{C} 3, \mathrm{C} 4$, and $\mathrm{B}$ were performed by single radial immunodiffusion according to Mancini et al. (24) using commercially available plates (Behring, Marburg, FRG). Clq, I, H, and P were quantitated by the same technique. Antisera to Clq, I, and $\mathrm{H}$ were obtained from Miles (Elkhart, IN), to P from Atlantic Antibodies (Scarborough, ME). C3d was measured in EDTA-plasma by rocketelectrophoresis as recently described (21). Prior to the run into an anti-C3d antibody containing gel EDTA-plasma had been treated with $12 \%$ polyethyleneglycol 6000 to precipitate $\mathrm{C} 3$ and $\mathrm{C} 3 \mathrm{~b}$ reactive with the anti-C3d antibody. The antiserum to C3d was obtained from DAKO (Copenhagen, Denmark). C3b was detected by crossed IEP as described by Weeke (25). The antiserum to C3 was purchased from Miles. Cleavage products of factor B were identified by IEP (26) using monospecific antiserum to B from Behring. Normal EDTA-plasma served as a negative control and zymosan-activated serum $\left(10 \mathrm{mg} / \mathrm{ml}, 30 \mathrm{~min}\right.$ at $\left.37^{\circ} \mathrm{C}\right)$ as a positive control.

If not specifically mentioned in the text all incubations were performed for 30 at $37^{\circ} \mathrm{C}$. For heat-inactivation sera were incubated for $30 \mathrm{~min}$ at $56^{\circ} \mathrm{C}$. A tandem-crossed IEP was performed to determine the electrophoretic mobility of residual $\mathrm{C} 3$-antigen present occasionally in some of the patient's reconvalescent sera. For this purpose two wells were filled on the same gel prior to the run in the first dimension. Well 1 contained RNS, well 2 NHS 1:10 diluted after a 5-min activation with heatAHG at $2 \mathrm{mg} / \mathrm{ml}$ and $37^{\circ} \mathrm{C}$. This activated serum served as a source for $\mathrm{C} 3$ and $\mathrm{C} 3 \mathrm{~b}$. AHG was prepared as described (21).

$\mathrm{C} 3 \mathrm{CoF}$ electrophoretic mobility was determined following electrophoresis in $1 \%$ agarose in barbital buffer pH 8.6 shown in scheme 1 . Following $2 \mathrm{~h}$ electrophoresis at $2 \mathrm{~V} / \mathrm{cm}$ the gel in the center of the slide (containing separated proteins to $100 \mu$ l RNS) was cut into $1-\mathrm{mm}$ slices and each slice added to $0.1 \mathrm{ml}$ of PBS. Fractions were eluted from the agarose by shaking for $1 \mathrm{~h}$ at room temperature. $\mathrm{C} 3 \mathrm{CoF}$ assay was performed with all fractions. Next horse antiserum to whole human serum (Behring) was added to the troughs and diffusion was allowed for $24 \mathrm{~h}$ in a moist chamber before the slide was washed and the precipitates stained with Coomassie blue. $\mathrm{C} 3 \mathrm{CoF}$ mobility was determined by comparing the maximum of $\mathrm{C} 3$ conversion in EDTA with the precipitin arcs of regular IEP.

For determination of $\mathrm{C} 3 \mathrm{CoF}$ molecular weight $1 \mathrm{ml}$ of patient's serum was separated by gel filtration using HPLC equipment (LKB, Bromma, Sweden) and a TSK-G SW 4000 blue column $(7.5 \times 600 \mathrm{~mm}, \mathrm{LKB})$. One-ml fractions were collected, and all protein-containing fractions were assayed for C3-converting activity in Mg-EGTA and EDTA as well as for IgG and IgM as internal marker proteins.

The patient's IgG-fraction and normal IgG were isolated by ammonium sulphate precipitation and DEAE 52 anion exchange chromatography as described by Johnstone and Thorpe (27). Further purification was achieved by gel filtration using a Sephadex G-200 column $(2.5 \times 30 \mathrm{~cm})$ and by affinity chromatography using a Sepharose CL 4B-protein A column $(13 \times 55$ $\mathrm{mm}$, Pharmacia, Freiburg, FRG) according to Patrick and Virella (28). With this material only one precipitin arc was found on IEP against anti-whole human serum and anti-human IgG (from rabbits, Behring). IgG-levels were determined by radial immunodiffusion using commercial plates (Behring) and adjusted to 
approximately $12 \mathrm{mg} / \mathrm{ml}$ by ultrafiltration using Amicon UM 30 (Lexington, MA) membranes. These IgG-fractions were used for crossed IEP experiments, the NFc and $\mathrm{C} 3 \mathrm{NeF}$ assay.

Euglobulin was precipitated by dialysis of $5 \mathrm{ml}$ of the patient's

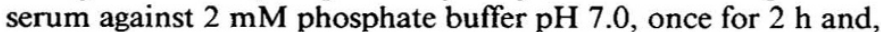
after buffer exchange, for $16 \mathrm{~h}$ at $4^{\circ} \mathrm{C}$. The euglobulin obtained was washed once using the same buffer. Following this precipitation step $\mathrm{C} 3 \mathrm{CoF}$ could not be dissolved at normal ionic strength and normal pH. It was only partly soluble in $0.5 \mathrm{ml}$ of $0.2 \mathrm{M}$ carbonate-bicarbonate buffer $\mathrm{pH}$ 9.6. Insoluble material was removed by centrifugation. Dissolved supernatant contained only $20 \%$ of the total initial $\mathrm{C} 3 \mathrm{CoF}$ activity. It was next dialyzed against $0.07 \mathrm{M}$ phosphate buffer pH 6.3 for $2 \mathrm{~h}$ at $4^{\circ} \mathrm{C}$ before it was applied to a Ultropac TSK DEAE column $(150 \times 7.5 \mathrm{~mm}$, LKB) equilibrated with the same buffer. After elution of the IgGpeak (void volume) using this buffer the "non-IgG" fraction was eluted by markedly increasing the ionic strength using $1 \mathrm{M} \mathrm{NaCl}$ dissolved in starting buffer. Protein concentrations were recorded by measuring absorbance at $280 \mathrm{~nm}$. The major peaks were pooled, concentrated by ultrafiltration, and assayed for IgG, C3 $\mathrm{NeF}$, and $\mathrm{C} 3 \mathrm{CoF}$ activity by crossed IEP against anti-C 3 antiserum after incubation of the fractions with NHS and the required chelating agent. In a representative experiment the IgG fraction after ultrafiltration had a volume of $0.35 \mathrm{ml}$ and a protein content of $0.67 \mathrm{~g} / \mathrm{dl}$, the non- $\mathrm{IgG}$ fraction a volume of $0.8 \mathrm{ml}$, and a protein content of $0.11 \mathrm{~g} / \mathrm{dl}$. The overall yield for $\mathrm{C} 3 \mathrm{CoF}$ in the latter fraction was approximately $8 \%$, the specific activity was about 8-fold higher than in original patient's serum.

$C 4 b, 2$ a stabilization assay. Basically the method of Halbwachs et al. (1) was used. Partially purified components $\mathrm{C} 1$ and $\mathrm{C} 2$ were prepared as described by Rapp and Borsos (22). C2 was oxidized.

Incubations. In the standard assay for $\mathrm{C} 3 \mathrm{CoF}$ activity 1 volume of the patient's serum was mixed with EDTA at a final concentration of $0.04 \mathrm{M}$ before 1 volume of NHS was added. The mixture was incubated for $30 \mathrm{~min}$ at $37^{\circ} \mathrm{C}$ before it was subjected to crossed IEP against anti-C3 antibody. If fractions eluted from the columns were tested for $\mathrm{C} 3 \mathrm{CoF}$ a 10:1 or 20:1 ratio (volume fraction: volume NHP1) was chosen to compensate dilution effects. EDTA was always added at a final concentration of $0.04 \mathrm{M}$. If incubations were performed in Mg-EGTA buffer a $0.02 \mathrm{M}$ concentration of EGTA and $0.005 \mathrm{M}$ for $\mathrm{Mg}^{2+}$ was used. The temperature dependence of $\mathrm{C} 3 \mathrm{CoF}$ action was determined by performing the standard assay at $0,10,20,30$, and $37^{\circ} \mathrm{C}$.

To find out if SBTI (Sigma, Munich, FRG) could diminish $\mathrm{C} 3 \mathrm{CoF}$ activity it was added at various concentrations between 0.1 and $5 \mathrm{mg} / \mathrm{ml}$ to the standard reaction mixture prior to incubation at $37^{\circ} \mathrm{C}$. The same procedure was used for DFP (Sigma).

$\mathrm{C} 3 \mathrm{NeF}$ activity was measured by activation of $\mathrm{C} 3$ in NHS by either heat-inactivated patient's serum or purified RN-IgG in Mg-EGTA buffer using crossed IEP.

Next attempts were made to eliminate $\mathrm{C} 3 \mathrm{CoF}$ from RNS by addition of monospecific antisera. The following antibodies were used (if concentration was required it was done by ultrafiltration, dilutions were made in PBS): IgG-fraction of rabbit anti-human IgG ( $\mathrm{h}$ - and 1 - chain, Cappell Lab., concentrated 10-fold), IgGfraction of goat anti-human C3 (Cappell, diluted 1:30), IgG fraction of goat anti-human C4 (Beckmann Instr., Munich, FRG, concentrated 4-fold), IgG fraction of rabbit anti-human factor B (Behring, concentrated 8-fold, sheep anti-human C2 (Seward Lab., London, England). Two volumes of RNS were mixed with 1 volume of $0.2 \mathrm{M}$ EDTA before 2 volumes of antiserum were added.

After $15 \mathrm{~min}$ at room temperature and $15 \mathrm{~min}$ at $0^{\circ} \mathrm{C}$ the precipitates were removed by centrifugation. In the control experiments physiological saline, nonimmune rabbit IgG and an IgG fraction of rabbit anti-human albumin (Behring, concentrated 8-fold) was used instead of antiserum. The remaining supernatants (under the conditions chosen free of the precipitated

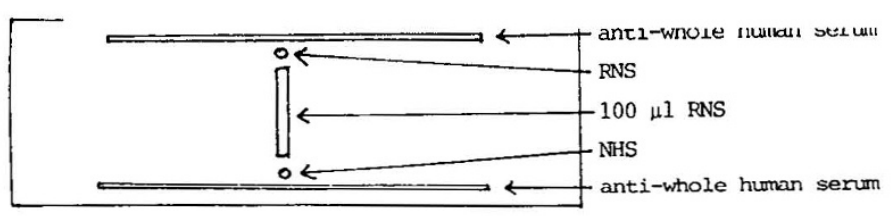

Scheme 1. Set up of wells in agarose for determination of $\mathrm{C} 3 \mathrm{CoF}$ electrophoretic mobility.

antigen by double diffusion, except for IgG and albumin) were next added to NHPl at a 2:1 (v/v) ratio and the mixture incubated for $30 \mathrm{~min}$ at $37^{\circ} \mathrm{C}$ before crossed IEP against anti-C3 was performed ( $\mathrm{C} 3 \mathrm{CoF}$ assay). The areas under $\mathrm{C} 3$ and $\mathrm{C} 3 \mathrm{~b}$ peaks were calculated planimetrically.

Affinity chromatography. Because IgG could not be completely eliminated by immune precipitation an affinity column was set up: $120 \mathrm{mg}$ of IgG-fraction of rabbit anti-human IgG (Cappell) were coupled to $\mathrm{CNBr}$-activated Sepharose 4B (Pharmacia, Uppsala, Sweden) at $7 \mathrm{mg} / \mathrm{ml}$ gel according to the instructions of the manufacturer. The resulting column size was $16 \times 65$ $\mathrm{mm}$. One-half $\mathrm{ml}$ of RNS was added and eluted with PBS at 30 $\mathrm{ml} / \mathrm{h}$. The material excluded from the column was concentrated by ultrafiltration to $3.29 \mathrm{~g} / \mathrm{dl}$ and assayed for IgG, C3 NeF, and C3 CoF.

\section{RESULTS}

Results of hemolytic titrations. Total hemolytic complement was hardly detectable and alternative pathway lysis undetectable. Components $\mathrm{C} 1, \mathrm{C} 4, \mathrm{C} 2$, and $\mathrm{C} 5$ were decreased and $\mathrm{C} 3$ was present in traces immunochemically and functionally. These traces could be identified as native $\mathrm{C} 3$ by tandem crossed IEP. $\mathrm{C} 7$ was slightly elevated and the other components were within the normal range [normal ranges have been reported (21)]. B, P, $\mathrm{I}$, and $\mathrm{H}$ were normal (immunochemically) and C3d-levels extremely elevated (above upper level of our standard curve). The hemolytic activity of $\mathrm{C} 1, \mathrm{C} 4$, and $\mathrm{C} 2$ was undetectable if EAC142-intermediates were not washed with $g^{2+}{ }^{2+}$ before $\mathrm{C}$ EDTA was added as a source of $\mathrm{C} 3-\mathrm{C} 9$.

Figure 1 shows the results of crossed IEP and IEP of $\mathrm{C} 3$ and $B$, respectively, in NHS following incubation with the patient's serum under various conditions. In the presence of Mg-EGTA the electrophoretic mobilities of both $\mathrm{C} 3$ and $\mathrm{B}$ were shifted to the position of the respective activated component. In the presence of EDTA, however, C3 was activated while B retained its normal electrophoretic mobility. This cleavage of $\mathrm{C} 3$ in normal human EDTA-plasma induced by RNS led to the definition of C3 converting factor, C3 CoF (Fig. 2). B cleavage could be induced in RNS if $\mathrm{C} 3(3 \mathrm{CH} 50 \mathrm{U} / \mathrm{ml}$, final mixture) was added prior to incubation instead of NHS as a source of $\mathrm{C} 3$. In contrast to cleavage of $\mathrm{C} 3$, however, $\mathrm{B}$ cleavage depended on the presence of $\mathrm{Mg}^{2+}$ (Fig. 3) suggesting activation via the alternative pathway.

Heat stability of the suspected activator of C3 was tested and the results are given in Table 1 . If NHS is incubated with ggvb ${ }^{2+}$ alone for $30 \mathrm{~min}$ at $37^{\circ} \mathrm{C}$ total hemolytic complement and hemolytic $\mathrm{C} 3$ are slightly decreased compared to the nonincubated control (data not shown). Incubation of NHS with heatinactivated NHS led to similar results. On incubation of NHS with heat-inactivated RNS an almost complete consumption of total hemolytic complement and $\mathrm{C} 3$ was observed. If EDTA was added to the latter mixture intermediate values for $\mathrm{CH} 50$ and C3 were obtained. Further experiments with heat-inactivated RNS were carried out by crossed IEP (Fig. 4). We notice that incubation of NHS alone leads to some activation of $\mathrm{C} 3(a)$. Addition of RNS markedly increases the amount of $\mathrm{C} 3 \mathrm{~b}$ generated $(b)$. Results in Mg-EGTA $(c)$ differ only slightly from $(b)$. In EDTA, however, most of C3 activation is blocked $(d)$ but still demonstrable. The appropriate control for experiment $(d)$ is the incubation of NHS in EDTA which does not generate C3 cleav- 


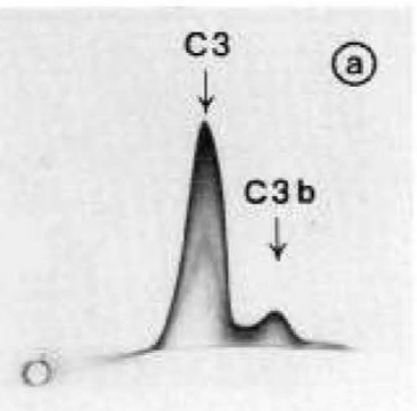

(a)

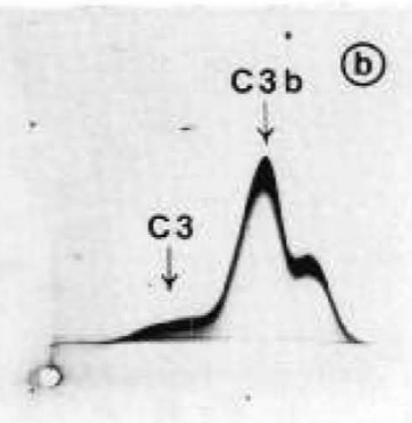

(b)

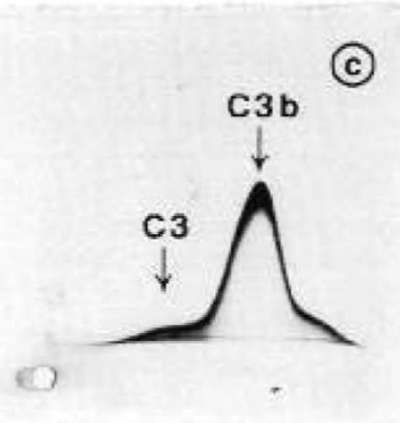

(c)

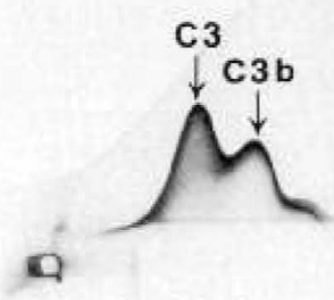

(d)
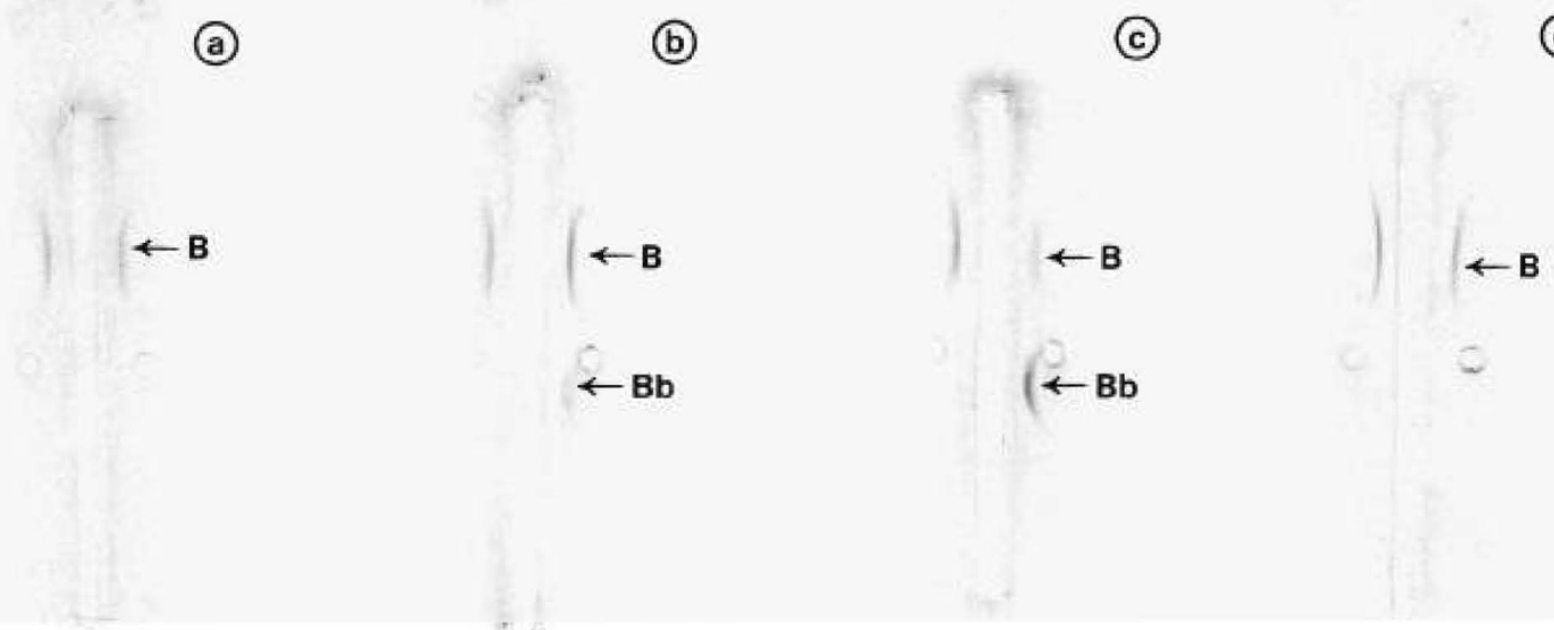

Fig. 1. Activation of $\mathrm{C} 3($ top $)$ and $\mathrm{B}($ bottom $)$ after incubation $\left(30 \mathrm{~min}\right.$ at $\left.37^{\circ} \mathrm{C}\right)$ of mixtures of NHS, RNS, and chelating agents. $a$ represent NHS + PBS (1:1), $b$, NHS + RNS, $c$, NHS + RNS + Mg-EGTA, and $d$, NHS + RNS + EDTA. On the IEP on the left NHP1 is always run as a control for native $\mathrm{B}$.
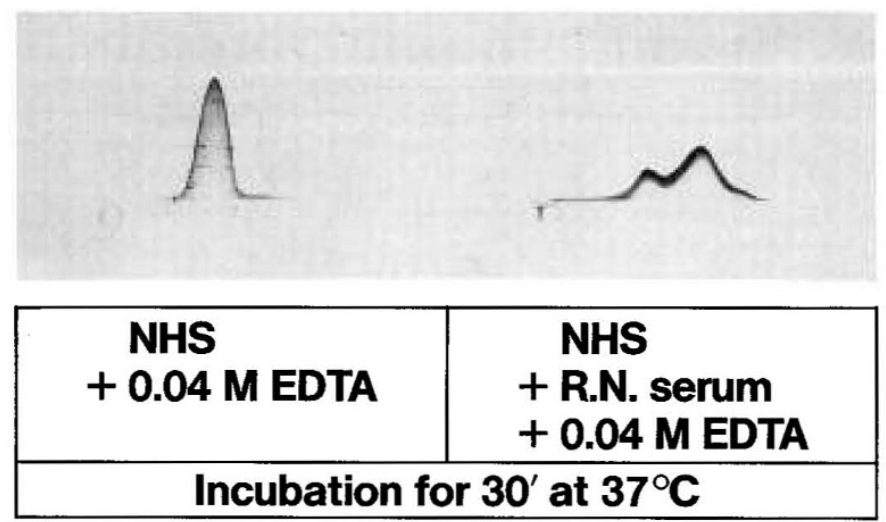

Fig. 2. Definition of $\mathrm{C} 3 \mathrm{CoF}$. Incubation of a 1:1 mixture for $30 \mathrm{~min}$ at $37^{\circ} \mathrm{C}$ of NHS and RNS in $0.04 \mathrm{M}$ EDTA led to significant generation of $\mathrm{C} 3 \mathrm{~b}$ not present in either serum alone. To add equal amounts of $\mathrm{C} 3$ antigen to both wells in well A PBS was used at the same volume as RNS in well $\mathrm{B}$.

age products $(e)$. Comparison of experiment $(d)$ with Figure 2 indicates loss of most of $\mathrm{C} 3 \mathrm{CoF}$ activity on treatment at $56^{\circ} \mathrm{C}$.

We initially expected only one activator of $\mathrm{C} 3$ to be present. Thus, to estimate the molecular weight of this activator RNS was subjected to gel filtration. After separation individual fractions were incubated with NHS and either Mg-EGTA or EDTA for $30 \mathrm{~min}$ at $37^{\circ} \mathrm{C}$. After crossed IEP against anti-C3 two peaks exhibited activating properties for $\mathrm{C} 3$ in vitro. In Mg-EGTA C3 was activated in the IgM and $\mathrm{IgG}$ region while in EDTA only the IgM-containing fraction was active (Fig. 5).

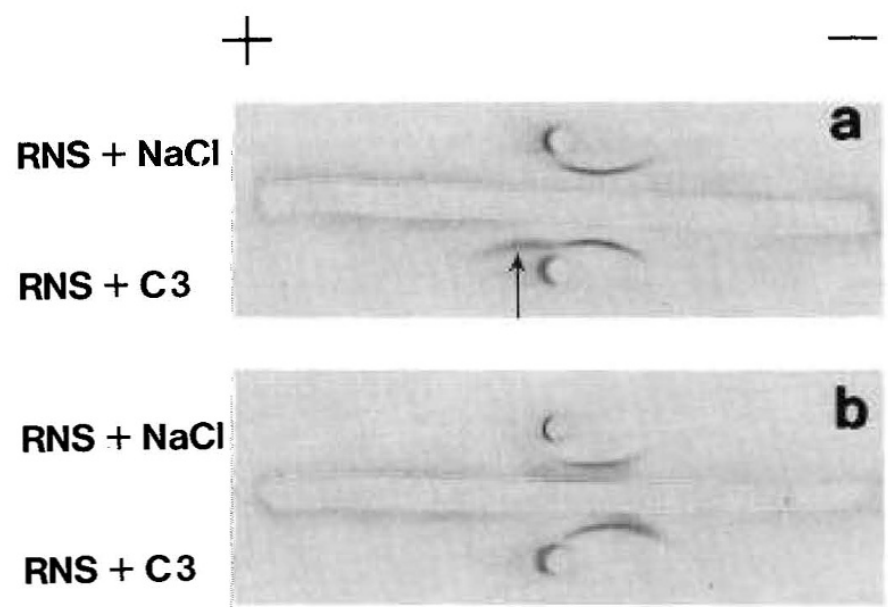

Fig. 3. IEP to detect $\mathrm{B}$ activation products following incubation for 30 min at $37^{\circ} \mathrm{C}$ of RNS with saline or functionally purified $\mathrm{C} 3(3 \mathrm{CH}$ $50 \mathrm{U} / \mathrm{ml}$ ) in Mg-EGTA $(a)$ or in EDTA $(b)$. After addition of C3 B can be activated in Mg-EGTA (arrow).

Further experiments were carried out with patient's IgG and normal IgG isolated under identical conditions. Figure 6 shows that incubation of RN-IgG with NHS induces significant activation of $C 3$. This was observed without chelating agents and in Mg-EGTA. However, if we used EDTA instead no activation of $\mathrm{C} 3$ could be achieved. Thus, the activating properties of RN-IgG were not identical with the activity attributed to $\mathrm{C} 3 \mathrm{CoF}$. RNIgG markedly activated C3 in Mg-EGTA buffer and was, thus, undistinguishable from $\mathrm{C} 3 \mathrm{NeF}$. $\mathrm{C} 3 \mathrm{CoF}$ was still unidentified. 
Since the patient's serum was able to convert C3 in NHS during incubation in EDTA there was a chance that $\mathrm{C} 3 \mathrm{CoF}$ was identical with an already stabilized classical pathway convertase $\mathrm{C} 4 \mathrm{~b}, 2 \mathrm{a}$. Therefore we analyzed whether preformed $\mathrm{C} 4 \mathrm{~b}, 2 \mathrm{a}$ was stabilized by $\mathrm{RN}-\mathrm{IgG}$ as reported $(1,16)$. EAC142 were prepared, washed, and resuspended in EDTA-buffer. One part of resuspended cells was incubated in the presence of RN-IgG, another part with identical concentration of normal IgG isolated in parallel. Samples were taken at intervals, washed, and lysed by the addition of guinea pig serum in $0.01 \mathrm{M}$ EDTA. The decay of $\mathrm{C} 2$ in the presence of RN-IgG and N-IgG was identical. NFc activity in patient's IgG was therefore excluded. However, C3 CoF could still be a prestabilized $\mathrm{C} 3$ convertase of either pathway. This possibility was next evaluated using monospecific antisera.

If RNS was treated with monospecific antisera prior to $\mathrm{C} 3$ CoF assay some antisera markedly reduced it's activity (the amount of $\mathrm{C} 3 \mathrm{~b}$ generated is expressed as percent $\mathrm{C} 3 \mathrm{~b}$ area divided by $\mathrm{C} 3+\mathrm{C} 3 \mathrm{~b}$ area). After treatment of RNS with saline $32 \%$ C $3 b$ were generated, with nonimmune rabbit IgG $35 \%$, and with antialbumin $36 \%$. With anti-C4 it was $34 \%$, with anti-C2 $29 \%$, with anti-IgG $13 \%$. After treatment with anti-C3 or anti-B antibody $\mathrm{C} 3 \mathrm{CoF}$ in the supernatant was no longer detectable. These data suggest the presence of $\mathrm{C} 3, \mathrm{~B}$, and IgG antigens in C3 CoF.

As IgG could not completely be precipitated by monospecific antibody it was absorbed out by affinity chromatography. The absorbed material had a protein concentration of $3.29 \mathrm{~g} / \mathrm{dl}$. IgG was below the level of detection by radial immunodiffusion $(0.8$ $\mathrm{mg} / \mathrm{dl}$ ) and $\mathrm{C} 3 \mathrm{NeF}$ and $\mathrm{C} 3 \mathrm{CoF}$ were absent.

On preparative electrophoresis in agarose $\mathrm{C} 3 \mathrm{CoF}$ activity was detected in the $\beta 2$-region. This also supported the concept that it is no IgG. Of the five temperatures tested most conversion of $\mathrm{C} 3$ could be induced at $37^{\circ} \mathrm{C}$ (Fig. 7) indicating that $\mathrm{C} 3 \mathrm{CoF}$ does not activate $\mathrm{C} 3$ in the cold.

We attempted to separate $\mathrm{C} 3 \mathrm{NeF}$ from $\mathrm{C} 3 \mathrm{CoF}$. We succeeded

Table 1. Complement consumption induced by RNS following heat-inactivation $\left(30 \mathrm{~min} \text { at } 56^{\circ} \mathrm{C}\right)^{*}$

\begin{tabular}{ccccc}
\hline & \multicolumn{4}{c}{ Mixture, incubated for $30^{\prime}$ at $37^{\circ} \mathrm{C}$} \\
\cline { 2 - 5 } & NHS & NHS & NHS & NHS + \\
Hemolytic & + & + & + & RNS $_{\text {hia }}+$ \\
titer & ggvb $^{++}$ & NHS $_{\text {hia }} \dagger$ & RNS $_{\text {hia }}$ & EDTA \\
\hline $\mathrm{CH} 50(\mathrm{U} / \mathrm{ml})$ & 87 & 90 & 15 & 48 \\
$\mathrm{C} 3(\mathrm{U} / \mathrm{ml})$ & 1400 & 1900 & 103 & 840 \\
\hline
\end{tabular}

* Incubation of NHS with ggvb ${ }^{++}$or heat-inactivated NHS does not lead to significant loss of hemolytic activity. Incubation with heatinactivated RNS leads to significant consumption of $\mathrm{CH} 50$ and $\mathrm{C} 3$. If EDTA is added at $10 \mathrm{mM}$ prior to addition of heatinactivated RNS intermediate titers for $\mathrm{CH} 50$ and $\mathrm{C} 3$ are obtained.

$\dagger$ Heat inactivated. using euglobulin precipitation and anion exchange chromatography on DEAE 52 using a discontinuous salt gradient to elute fractions. The elution profile is depicted in Figure 8. Peak I contained $630 \mathrm{mg} / \mathrm{dl}$ of protein and $463 \mathrm{mg} / \mathrm{dl}$ of $\mathrm{IgG}$ and

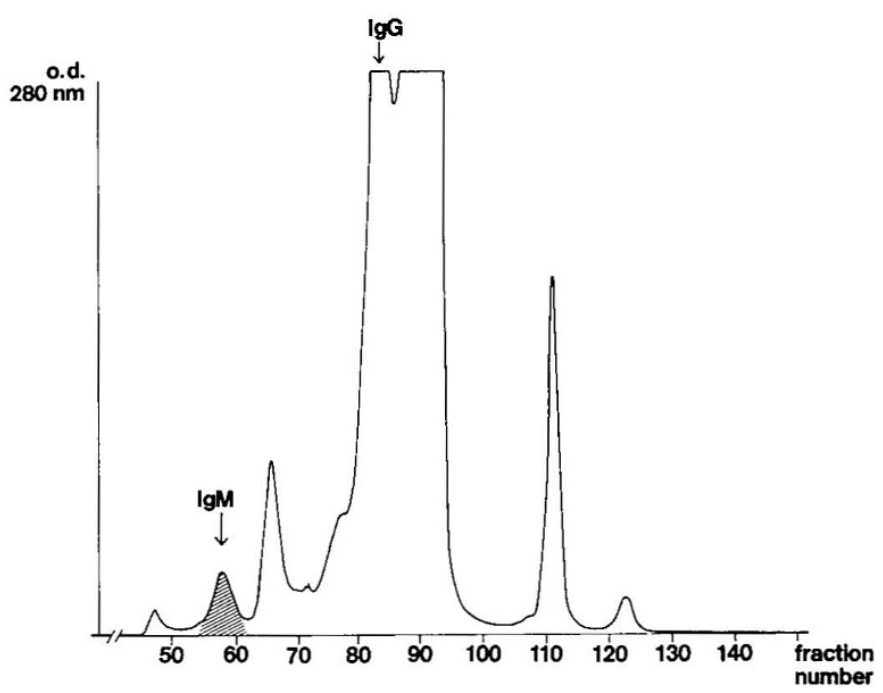

Fig. 5. Elution profile of RNS after separation on a TSK-G SW 4000 blue column $(7.5 \times 600 \mathrm{~mm})$. Internal markers IgG and IgM are indicated by arrows. C3 conversion in Mg-EGTA could be induced by both the IgG and IgM containing peaks and C 3 conversion in EDTA by the IgM containing peak only (indicated by the shaded area). Thus, it can be expected to have a molecular weight similar to IgM.

\section{3}

C 3b

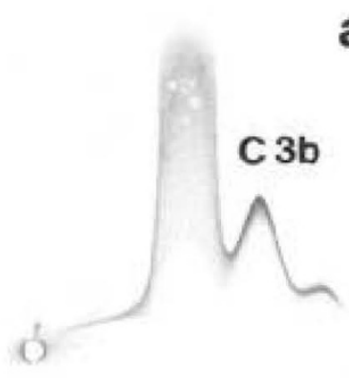

NHS + N-IgG

NHS + RN-IgG

Fig. 6. Incubation of NHS with either normal $\operatorname{lgG}(\mathrm{N}-\mathrm{IgG})$ or patient's IgG (RN-IgG). While with $\mathrm{N}-\mathrm{IgG}$ only little activation is achieved (a) addition of RN-IgG $(b)$ led to almost total consumption of C3.

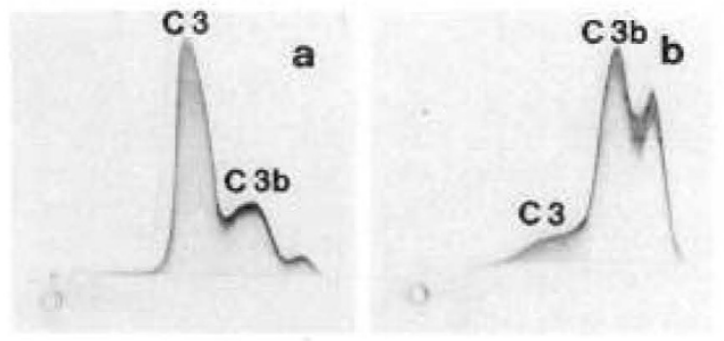

NHS alone
NHS + RNS (hia)

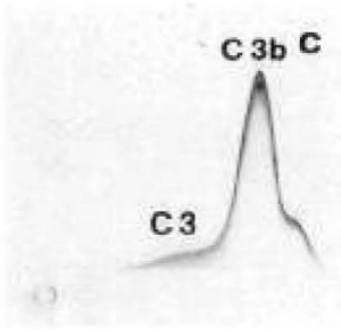

NHS + RNS (hia)

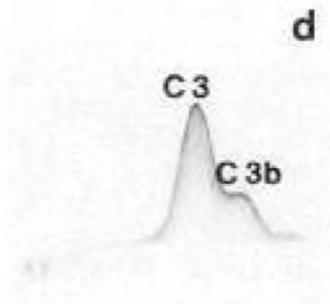

NHS + RNS (hia) + EDTA

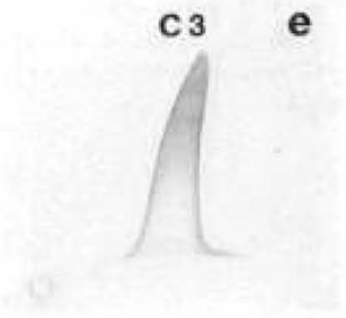

NHS + EDTA

Fig. 4. Crossed IEP against anti-C 3 antibody after incubation $\left(30 \mathrm{~min}, 37^{\circ} \mathrm{C}\right)$ of various mixtures: $(a)$ contains NHS alone, $(b)$ contains a mixture of NHS and heat-inactivated RNS without chelating agents, $(c)$ is the experiment $(b)$ but with Mg-EGTA added, in $(d)$ Mg-EGTA is replaced by EDTA. $(e)$ is NHS incubated in EDTA. Incubation of NHS alone in Mg-EGTA was deleted because the result was identical with $(a)$. 


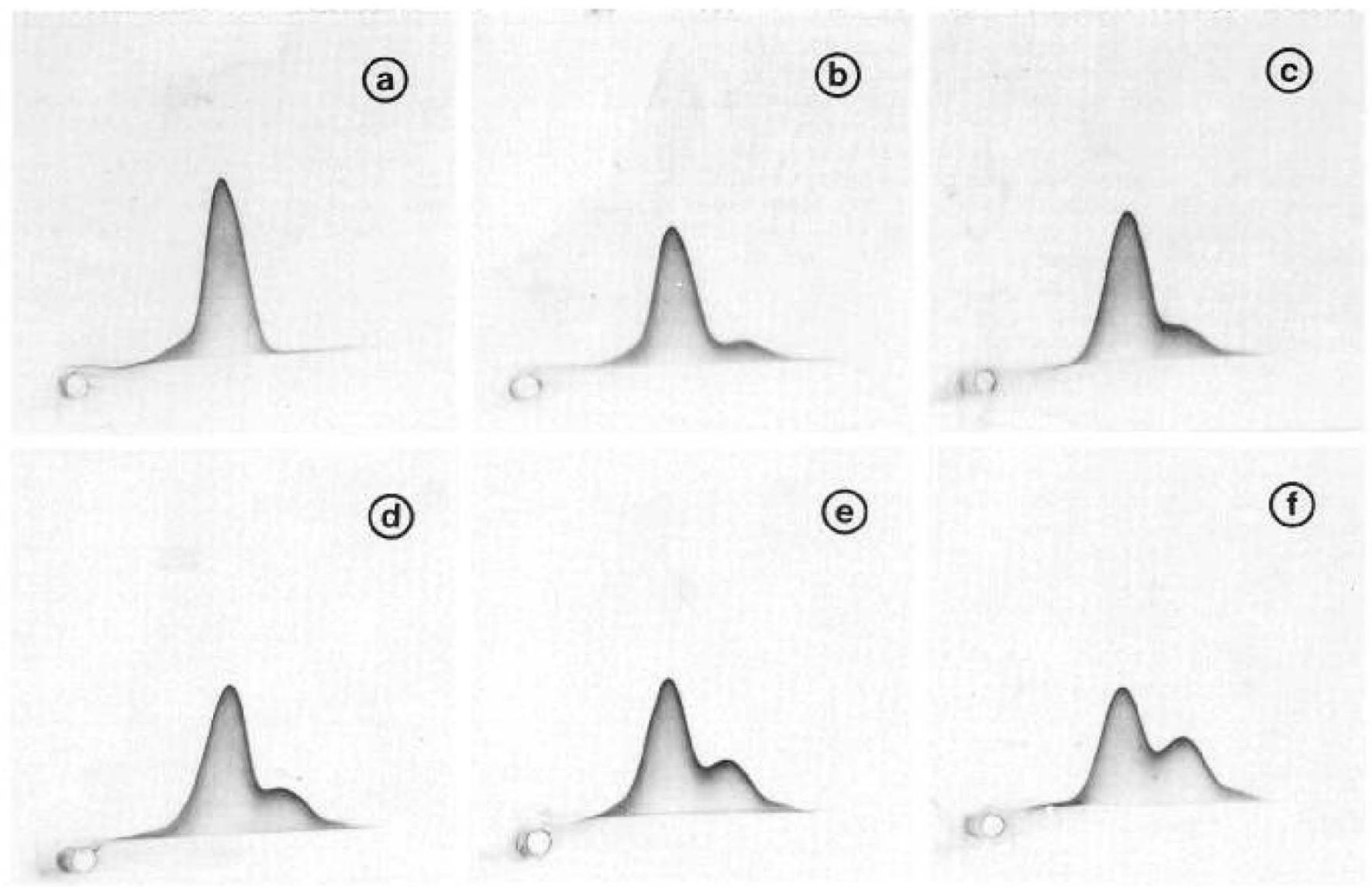

Fig. 7. Influence of temperature on the activity of $\mathrm{C} 3 \mathrm{CoF}$ (standard assay mixture). RNS is one of the recent specimens and not identical with the one in Figure 3. Experiment $a$ is the control (NHS + PBS + EDTA), in the others PBS is replaced by RNS before incubation at various temperatures $\left(b 0^{\circ} \mathrm{C}, c 10^{\circ} \mathrm{C}, d 20^{\circ} \mathrm{C}, e 30^{\circ} \mathrm{C}\right.$, and $\left.f 37^{\circ} \mathrm{C}\right)$.

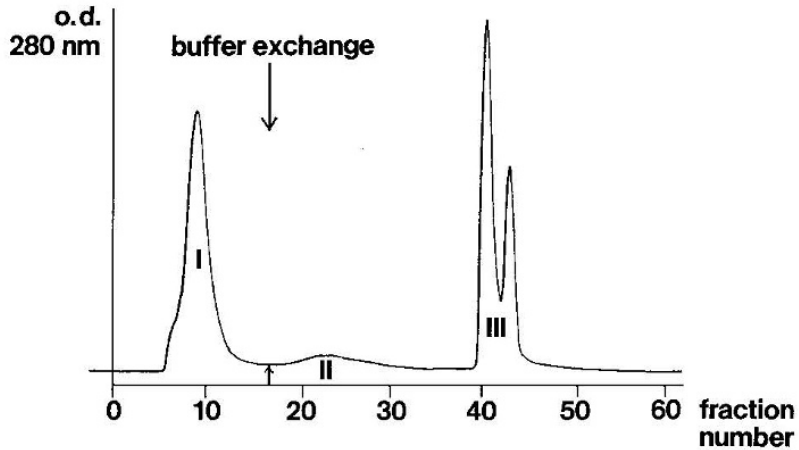

Fig. 8. Separation of $\mathrm{C} 3 \mathrm{NeF}$ and $\mathrm{C} 3 \mathrm{CoF}$. The patient's euglobulin is dissolved and applied to a DEAE column (as described under "Materials and methods") equilibrated with $0.1 \mathrm{M}$ phosphate buffer $\mathrm{pH} 7.2$. After elution of the first major peak (mainly IgG) the starting buffer is replaced by a $0.1 \mathrm{M}$ phosphate buffer containing $1 \mathrm{M}$ sodium chloride (the buffer exchange is indicated by the arrow). All three peaks were pooled, concentrated by ultrafiltration, and assayed for IgG, $\mathrm{C} 3 \mathrm{NeF}$, and $\mathrm{C} 3 \mathrm{CoF}$. Peak I contained mainly $\mathrm{IgG}$ and $\mathrm{C} 3 \mathrm{NeF}$ activity but was devoid of $\mathrm{C} 3 \mathrm{CoF}$. Peak II contained traces of $\mathrm{IgG}$ as well as $\mathrm{C} 3 \mathrm{NeF}$ but no C3 CoF. Peak III contained only traces of IgG but most of $\mathrm{C} 3 \mathrm{CoF}$ activity. Pool III also activated C3 in Mg-EGTA.

activated C3 in Mg-EGTA but not in EDTA. Peak II contained only little protein and no C3 activator. Peak III contained (after repeated ultrafiltration) $580 \mathrm{mg} / \mathrm{dl}$ of protein and orily traces of IgG but activated $\mathrm{C} 3$ in the presence of $0.04 \mathrm{M}$ EDTA. This strongly suggests that $\mathrm{C} 3 \mathrm{CoF}$ is no IgG.
To exclude that $\mathrm{C} 3 \mathrm{CoF}$ is a trypsin-like enzyme inhibition studies were performed using SBTI. No inhibition was noticed up to a concentration of $5 \mathrm{mg} / \mathrm{ml}$ in the final solution. In contrast, DFP produced dose-dependant inhibition of $\mathrm{C} 3 \mathrm{CoF}$ activity up to approximately $50 \%$ at $5 \mathrm{mM}$.

\section{DISCUSSION}

In an 11-yr-old girl with meningococcal septicemia hypercatabolism of $\mathrm{C} 3$ with undetectable $\mathrm{C} 3$ and extremely high levels of $\mathrm{C} 3 \mathrm{~d}$ persisted as long as $3 \mathrm{yr}$ after complete recovery. This hypercatabolism was due to the presence of two different C3 activators with different biochemical properties.

The first activator was found to be heat stable, $\mathrm{Mg}^{2+}$ dependent, and did copurify with IgG. It markedly activated C3 in MgEGTA. The decay of the classical pathway convertase $C 4 b, 2 a$, in the presence of $\mathrm{RN}-\mathrm{IgG}$, was unaffected. Thus, this first activator did not raise our interest because it seemed to be a well known activator of $\mathrm{C} 3, \mathrm{C} 3$ nephritic factor $\mathrm{C} 3 \mathrm{NeF}$.

As $\mathrm{C} 3 \mathrm{CoF}$ action is independent from divalent cations it must be different from all $\mathrm{Mg}^{2+}$-dependent activators described. Theoretically, it could be a stabilized $\mathrm{C} 3$ convertase of either pathway. If $\mathrm{C} 3 \mathrm{CoF}$ was identical with $\mathrm{NFc}$-stabilized $\mathrm{C} 4 \mathrm{~b}, 2 \mathrm{a}$ one should expect at least some free circulating NFc in the patients IgG-fraction as described (1); but no such activity was found. In addition, we failed to eliminate $\mathrm{C} 3 \mathrm{CoF}$ by immunoprecipitation with anti-C4 or anti-C2. In contrast, it was completely eliminated by immunoprecipitation with anti-C3 and anti-B and partly eliminated with anti-IgG. Using an anti-IgG affinity column C3 CoF was completely absorbed out together with $\mathrm{IgG}$ and $\mathrm{C} 3$ $\mathrm{NeF}$. The most plausible explanation for these results is the simultaneous occurrence of free $\mathrm{C} 3 \mathrm{NeF}$ with a C3 NeF-stabilized 
AP C3 convertase $(\mathrm{C} 3 \mathrm{CoF})$. If this is so, it would indicate that if the regular "negative" controls for $\mathrm{C} 3 \mathrm{NeF}$ assays are "slightly positive" $\mathrm{C} 3 \mathrm{CoF}$ may be present. Future studies will have to focus on the mechanism that allows the formation and persistence of $\mathrm{C} 3 \mathrm{CoF}$.

Sensitivity of C3 CoF to inhibition with DFP further supports the concept that it is a serine protease despite the fact that in serum only $50 \%$ inhibition could be achieved while Medicus et al. (29) achieved $80 \%$ in a serum-free system. In serum DFP might be absorbed to other proteins. An interesting observation was the absence of hemolytic $\mathrm{C} 1, \mathrm{C} 4$, and $\mathrm{C} 2$ in RNS when we applied the complement technology generally used. This technology works on the assumption that lysis of EAC142 can be achieved by the addition of C-EDTA as a source of C3-C9. EDTA is said to prevent generation of $\mathrm{C} 3$ convertases of either pathway. Serial dilutions of RNS containing C3 CoF obviously activated guinea pig $\mathrm{C} 3$ making a $\mathrm{C} 5-\mathrm{C} 9$ reagent of C-EDTA which was unable to lyse EAC142 cells. Washing EAC142 intermediates prior to the addition of C-EDTA eliminated $\mathrm{C} 3 \mathrm{CoF}$ and preserved guinea pig $\mathrm{C} 3$ hemolytic activity allowing correct titration of $\mathrm{C} 1, \mathrm{C} 4$, and $\mathrm{C} 2$.

While $\mathrm{C} 3 \mathrm{NeF}$ induced activation of $\mathrm{C} 3$ and $\mathrm{B}$ without chelating agents and in Mg-EGTA, B remained uncleaved in EDTA. This indicates that $\mathrm{C} 3 \mathrm{NeF}$ requires newly formed $\mathrm{C} 3 \mathrm{~b}, \mathrm{Bb}$ for its action while $\mathrm{C} 3 \mathrm{CoF}$ seems to act independently from either convertase. B in RNS was present in normal concentrations and, despite the presence of $\mathrm{C} 3 \mathrm{NeF}$, had normal electrophoretic mobility. This can easily be explained as follows. Initiation of the alternative pathway of complement requires native $\mathrm{C} 3$ for formation of $\mathrm{C} 3\left(\mathrm{H}_{2} \mathrm{O}\right)$. This so-called $\mathrm{C} 3 \mathrm{~b}$-like $\mathrm{C} 3$ reacts with $\mathrm{B}$ in the presence of $\mathrm{Mg}^{2+}$ and factor $\mathrm{D}$ to $\mathrm{C} 3\left(\mathrm{H}_{2} \mathrm{O}\right), \mathrm{Bb}$. $\mathrm{B}$ is activated during this step. The patient's serum was devoid of $\mathrm{C} 3$ so that initiation of the AP was impossible. However, if additional C3 was provided by either NHS or isolated C3 in the presence of $\mathrm{Mg}^{2+}$, AP activation was facilitated. In EDTA, however, only $\mathrm{C} 3 \mathrm{CoF}$ acted upon $\mathrm{C} 3$ to form $\mathrm{C} 3 \mathrm{a}$ and $\mathrm{C} 3 \mathrm{~b}$ while cleavage of B was prevented.

In summary, it seems that under conditions that we are unsure of $\mathrm{C} 3 \mathrm{NeF}$ binds to $\mathrm{C} 3 \mathrm{~b}, \mathrm{Bb}$ to form a chronically circulating AP $\mathrm{C} 3$ concertase $(\mathrm{C} 3 \mathrm{CoF})$. $\mathrm{C} 3 \mathrm{CoF}$, once formed, acts independently from divalent cations. Its presence should be considered if "negative" controls for $\mathrm{C} 3 \mathrm{NeF}$ turn out to be positive, or if hemolytic titrations of $\mathrm{C} 1, \mathrm{C} 4$, and $\mathrm{C} 2$ are close to zero in the presence of normal amounts of antigens.

\section{REFERENCES}

1. Halbwachs LM, Leveille M, Lesavre P, Wattel S, Leibovitch J 1980 Nephritic factor of the classical pathway of complement. J Clin Invest 65:1249-1256

2. Thompson RA, Winterborn MH 1981 Hypocomplementemia due to a genetic deficiency of $\beta 1 \mathrm{H}$ globulin. Clin Exp Immunol 46:110-119

3. Alper CA, Abramson N, Johnston RB, JandI JH, Rosen FS 1970 Increased susceptibility to infection associated with abnormalities of complement mediated functions of the third component of complement (C3). N Engl J Med 282:349-354

4. Carlo JR, Ruddy S, Studer EJ, Conrad DH 1979 Complement receptor binding to $\mathrm{C} 3 \mathrm{~b}$-coated cells treated with $\mathrm{C} 3 \mathrm{~b}$ inactivator, $\beta 1 \mathrm{H}$ globulin and trypsin.
J Immunol 123:523-528

5. Gaither TA, Hammer CH. Frank MM 1979 Studies of the molecular mechanism of $\mathrm{C} 3 \mathrm{~b}$ inactivation and a simplified assay of $\mathrm{B} 1 \mathrm{H}$ and the $\mathrm{C} 3 \mathrm{~b}$ inactivator. J Immunol 123:1195-1204

6. Kazatchkine MD, Nydegger UE 1982 The human alternative complement pathway: Biology and immunopathology of activation and regulation. Prog Allergy 30:193-234

7. Theofilopoulos AN, Dixon FJ 1979 The biology and detection of immune complexes. Adv Immunol 28:89-221

8. Spitzer RE, Vallota EH, Forristal J, Sudora E, Stitzel A, Davis NC, West CD 1969 Serum C3 lytic system in patients with glomerulonephritis. Science 164:436-437

9. Sissons JGP, West RJ, Fallows J, Williams DG, Boucher BJ, Amos N, Peters DK 1976 The complement abnormalities of lipodystrophy. N Engl J Med 294:461-465

10. Thompson RA, Yap PL, Brettle RB, Dunmow RE, Chapel H 1983 Meningococcal meningitis associated with persistent hypocomplementemia due to circulating C3 nephritic factor. Clin Exp Immunol 52:153-156

11. Daha MR, van Es LA 1979 Further evidence for the antibody nature of C3 nephritic factor (C3 NeF). J Immunol 123:755-758

12. Scott DM, Amos N, Sissons JGP, Lachmann PJ, Peters DK 1978 The immunoglobulin nature of nephritic factor (NeF). Clin Exp Immunol 32:12-24

13. Daha MR, Fearon DT, Austen KF $1976 \mathrm{C} 3$ nephritis factor (C3 NeF): stabilization of fluid phase and cell-bound alternative pathway convertase. Immunol 116:1-7

14. Daha MR, Hazevoet HM, van Es LA 1983 Regulation of immune complexmediated complement activation by autoantibodies (F-42) isolated from sera from patients with systemic lupus erythematosus. Clin Exp Immuno $53: 541-546$

15. Daha MR, van ES LA 1980 Relative resistance of the F-42-stabilized classical pathway $\mathrm{C} 3$ convertase to inactivation to inactivation by $\mathrm{C} 4$-binding protein. J Immunol 125:2051-2054

16. Gigli I, Sorvillo J, Halbwachs LM, Leibowitch J 1981 Mechanism of action of the $C 4$ nephritic factor: degradation of the classical pathway $\mathrm{C} 3$ convertase. J Exp Med 154:1-12

17. Leibowitch J, Leveille M, Halbwachs L 1979 Description d'une activite enzymatique inhabituelle clivant le 3e composant du complement. C R Acad Sci Paris 288:567-569

18. Alper CA, Block KJ, Rosen FS 1973 Increased susceptibility to infection in a patient with type II essential hypocomplementemia. N Engl J Med 288:601 606

19. Bartlow BG, Roberts JL, Lewis EJ 1979 Nonimmunoglobulin C3 activating factor in membranoproliferative glomerulonephritis. Kidney Int 15:294-302

20. Mayer MM 1961 Complement and complement fixation. In: Kabat $F$, Maye MM (eds) Experimental Immunochemistry 2nd ed. Charles C Thomas, Springfield, IL, pp 133-240

21. Wahn V 1982 Intravenöse Gammaglobulintherapie-Messung von zirkulierenden Immunkomplexen und Komplementfaktoren. Thieme, Stuttgart

22. Rapp HJ, Borsos T 1970 Molecular Basis of Complement Action. Appleton Centurty Crofts, New York

23. Platts-Mills TAE, Ishizaka K 1974 Activation of the alternative pathway of human complement by rabbit cells. J Immunol 113:348-358

24. Mancini JA, Carbonara O, Heremans JF 1965 Immunochemical quantitation of antigen by single radial immunodiffusion. Immunochemistry 2:235-242

25. Weeke B 1973 Crossed immunoelectrophoresis. In: Axelsson NH, Kroll J, Weeke B (eds) A Manual of Quantitative Immunoelectrophoresis. Scand J Immunol [Suppl] 1:47-56

26. Day NK, Schreiber RD, Götze O, Müller-Eberhard HJ 1976 Reversible activation of proactivator (factor B) of the alternative pathway without cleavage of the molecule. Scand J Immunol 5:715-720

27. Johnstone A, Thorpe R 1982 Immunochemistry in Practice. Blackwell Scientific Publications, Oxford, pp 44-46

28. Patrick CC. Virella G 1978 Isolation of normal human IgG3. Identical molecular weight for normal and monoclonal gamma-3 chains. Immunochemistry 15:137-139

29. Medicus RG, Götze O, Müller-Eberhard HJ 1976 The serine protease nature of the $\mathrm{C} 3$ and $\mathrm{C} 5$ convertases of the classical and alternative complemen pathways. Scand J Immunol 5:1049 